\title{
Cystic duct dysplasia after cholecystectomy: a systematic review of the literature
}

\author{
Francesco Mongelli $^{1}{ }^{*}$, Agnese Cianfarani ${ }^{1}$, Matteo Di Giuseppe ${ }^{1}$, \\ Antonjacopo Ferrario Di Tor Vajana ${ }^{1}$, Andrea Saporito ${ }^{2}$, Fabio Garofalo ${ }^{3}$, Davide La Regina ${ }^{1}$
}

\author{
${ }^{1}$ Department of Surgery, ${ }^{2}$ Department of Perioperative Medicine, Ospedale Regionale di Bellinzona e Valli, 6500 \\ Bellinzona, Switzerland \\ ${ }^{3}$ Department of Surgery, Ospedale Regionale di Lugano, 6900 Lugano, Switzerland.
}

Received: 04 September 2019

Accepted: 07 October 2019

\author{
*Correspondence: \\ Dr. Francesco Mongelli, \\ E-mail: francesco.mongelli@mail.com
}

Copyright: (c) the author(s), publisher and licensee Medip Academy. This is an open-access article distributed under the terms of the Creative Commons Attribution Non-Commercial License, which permits unrestricted non-commercial use, distribution, and reproduction in any medium, provided the original work is properly cited.

\begin{abstract}
Approximately 1 to $3.5 \%$ of cholecystectomies are found to have incidental dysplasia on histological examination. Cases of positive resection margins on the cystic stump are rare and evidence lack. The aim of this article was to systematically review the literature and to suggest a possible management algorithm. We searched PubMed, Cochrane Library and Google Scholar databases by combining "cholecystectomy" and "dysplasia" and "cystic" according to preferred reporting items for systematic reviews and meta-analyses guidelines. Studies providing information about cystic duct dysplasia with positive resection margin after cholecystectomy were included. We identified 113 articles, of which three were considered eligible. Five patients had a high-grade dysplasia, one patient had a carcinoma and one had a low-grade dysplasia. Median follow-up was of 10.5 months (range: 0.5-26.6 months), no evidence of recurrence was found in patients with dysplasia, while the patient with diagnosis of cholangiocarcinoma died during follow-up. Patients with positive resection margins for dysplasia after cholecystectomy should be considered for a surgical treatment according to clinical and pathological factors. Simple cystic duct stump excision was suggested and seems to be safe and effective with no evidence of recurrence during follow-up when a R0 resection is achieved. A multidisciplinary approach and a surveillance program should be always taken into account.
\end{abstract}

Keywords: Gallstone, Cystic duct, Cystic stump, Dysplasia, Cholecystectomy

\section{INTRODUCTION}

Gallstone disease is an extremely widespread disease, being the estimated prevalence around $10-15 \%$ in adult population. Symptoms leading to cholecystectomy can be identified in up to $35 \%$ of patients with cholecystolithiasis, making the laparoscopic cholecystectomy one of the most commonly performed surgical operations in developed countries. ${ }^{1,2}$ Approximately 1 to $3.5 \%$ of cholecystectomies are found to have incidental dysplasia on histological examination. ${ }^{3-}$ ${ }^{5}$ Biliary dysplasia is considered a risk factor for the development of an invasive carcinoma. ${ }^{6}$ Usually, dysplasia does not reach the resection margin, so that no further treatment is needed after cholecystectomy. ${ }^{7}$ The clinical implications and management of the resection margin involvement by dysplastic changes are unknown.

In this article, we discuss the matter and suggest a possible management algorithm.

\section{METHODS}

\section{Search strategy}

Two researchers independently searched the PubMed, Cochrane Library and Google Scholar databases by combining "cholecystectomy" and "dysplasia" and 
"cystic" (last update: June 1 2019) according to the preferred reporting items for systematic reviews and meta-analyses (PRISMA) guidelines. ${ }^{8}$ No informed consent nor institutional review board were needed since this article is based on published data.

\section{Inclusion and exclusion criteria}

Studies providing adequate information about the cystic duct or stump dysplasia after cholecystectomy on the histopathological examination were included. Studies were excluded in case of a proved diagnosis of gallbladder or cystic duct cancer.

\section{Study selection and quality assessment}

Two reviewers independently evaluated titles and abstracts to choose potential studies. If data were duplicated or overlapping, only the most recent data were included. Studies not matching inclusion and exclusion criteria were discarded. Studies potentially suitable for inclusion were evaluated in full-text. Disagreements were resolved by discussion. The evidence quality of was assessed with the Grading of recommendations, assessment, development and evaluations (GRADE approach). 9 In particular, it was rated from 4 to 1 , corresponding 4 to a high level of evidence, 3 to moderate, 2 to low and 1 to very low. With this methodology, the risk of bias, inconsistency, indirectness, imprecision and publication bias were considered to possibly reduce the quality of evidence by 1 or 2 points according to the importance of the factor itself.

\section{RESULTS}

The searches identified 109 articles from PubMed and 4 articles from Cochrane Library and Google Scholar. After removing duplicates, 110 studies remained. Abstracts and titles were screened and 12 articles were considered potentially eligible. Full texts of these studies were retrieved and analysed. Nine studies were excluded because did not match inclusion and exclusion criteria. Finally, three studies were found eligible and considered in this systematic review. ${ }^{10-12}$ The characteristics of the included studies are given in Table 1 .

Seven patients were found in the medical literature. Median age at the moment of the diagnosis was 61 years old (range: 36-77). Pre-operative radiographic abnormalities were detected only in 2 out of 7 patients. Four patients had simple cystic duct resection with one 1 case of bile duct exploration for gallstone, 1 patient had cystic duct resection with lymphadenectomy and IV and $\mathrm{V}$ segments hepatectomy, 2 patients had bile duct resection with lymphadenectomy, in 1 case with associated IV and V segments hepatectomy. Five patients were found to have post-operative high-grade dysplasia, one patient had a carcinoma and one had a low-grade dysplasia. Median follow-up was of 10.5 months (range: 0.5-26.6 months), no evidence of recurrence was found in patients with dysplasia. The patient with pathological diagnosis of cholangiocarcinoma died during follow-up after 15.3 months after surgery. Based on these considerations the proposal for a therapeutic algorithm is presented in Figure 2.
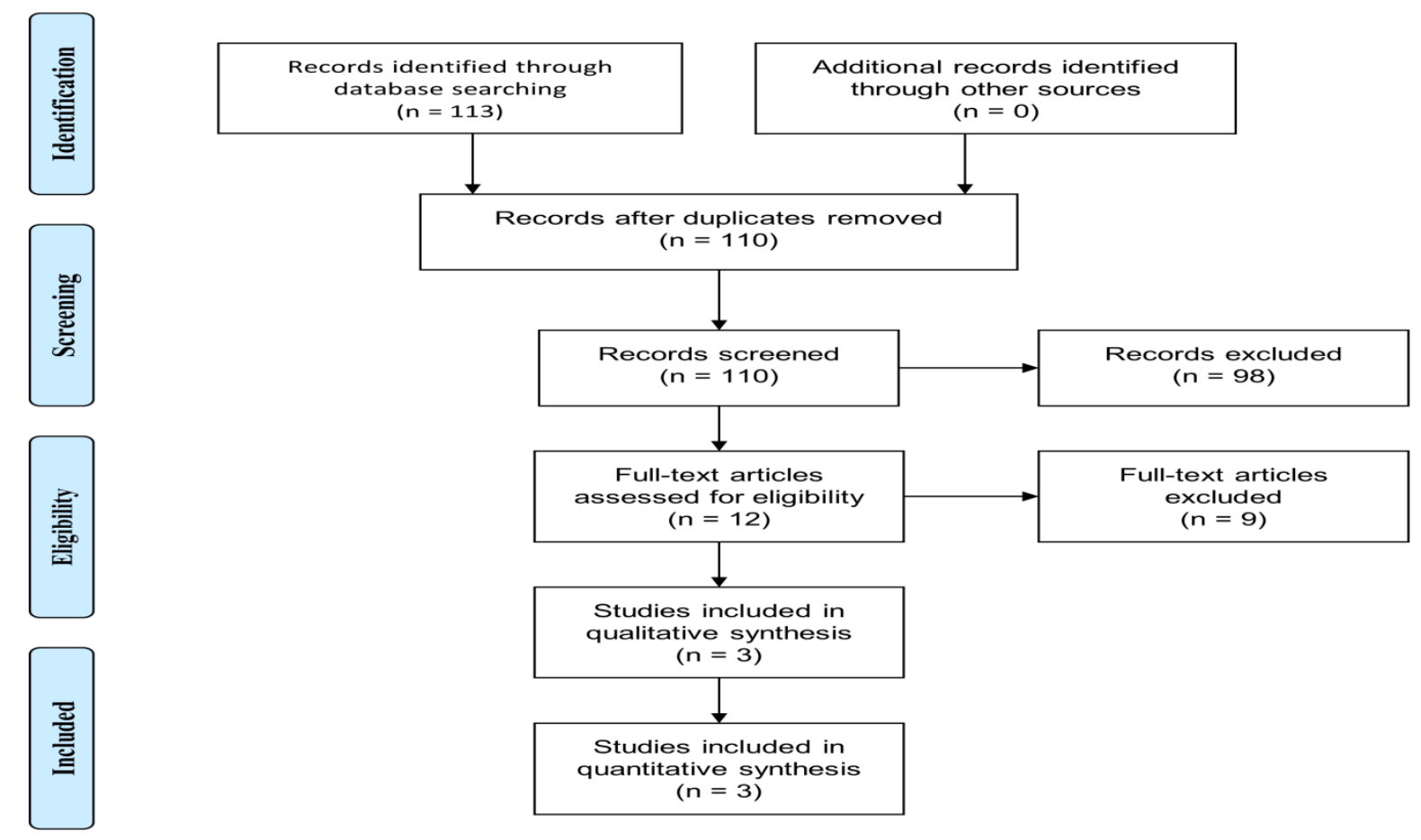

Figure 1: Literature search according to PRISMA guidelines. 
Table 1: Patients characteristics of included studies.

\begin{tabular}{|c|c|c|c|c|c|c|c|}
\hline & Patient 1 & Patient 2 & Patient 3 & Patient 4 & Patient 5 & Patient 6 & Patient 7 \\
\hline Sex & Male & Female & Male & Male & Female & Female & Female \\
\hline $\begin{array}{l}\text { Age (in } \\
\text { years) }\end{array}$ & 66 & 77 & 61 & 65 & 57 & 36 & 44 \\
\hline $\begin{array}{l}\text { Preoperative } \\
\text { imaging }\end{array}$ & MRCP & $\mathrm{PET} / \mathrm{CT}$ & MRCP & $\begin{array}{l}\text { CT } \\
\text { MARCP }\end{array}$ & $\begin{array}{l}\text { MRCP } \\
\text { ERCP }\end{array}$ & $\begin{array}{l}\text { CT } \\
\text { MRCP } \\
\text { ERCP }\end{array}$ & $\begin{array}{l}\text { No } \\
\text { preoperative } \\
\text { images }\end{array}$ \\
\hline $\begin{array}{l}\text { Preoperative } \\
\text { pathology }\end{array}$ & $\begin{array}{l}\text { High-grade } \\
\text { dysplasia }\end{array}$ & $\begin{array}{l}\text { High-grade } \\
\text { dysplasia }\end{array}$ & $\begin{array}{l}\text { High-grade } \\
\text { dysplasia }\end{array}$ & $\begin{array}{l}\text { High-grade } \\
\text { dysplasia }\end{array}$ & $\begin{array}{l}\text { High- } \\
\text { grade } \\
\text { dysplasia }\end{array}$ & $\begin{array}{l}\text { High-grade } \\
\text { dysplasia }\end{array}$ & $\begin{array}{l}\text { Low-grade } \\
\text { dysplasia }\end{array}$ \\
\hline $\begin{array}{l}\text { Radiographic } \\
\text { abnormality }\end{array}$ & $\begin{array}{l}\text { Mildly } \\
\text { dilated } \\
\text { cystic duct } \\
\text { stump } \\
\text { Borderline } \\
\text { enlarged } \\
\text { lymph } \\
\text { node }\end{array}$ & $\begin{array}{l}\text { No } \\
\text { suspicious } \\
\text { findings }\end{array}$ & $\begin{array}{l}\text { No } \\
\text { suspicious } \\
\text { findings }\end{array}$ & $\begin{array}{l}\text { Minimal } \\
\text { thickening } \\
\text { of cystic } \\
\text { stump } \\
\text { Small } \\
\text { lesions in } \\
\text { segments } \\
\text { III and IV } \\
\text { of the liver }\end{array}$ & $\begin{array}{l}\text { No } \\
\text { suspiciou } \\
\mathrm{s} \\
\text { findings }\end{array}$ & $\begin{array}{l}\text { No } \\
\text { suspicious } \\
\text { findings }\end{array}$ & - \\
\hline Operation & $\begin{array}{l}\text { Bile duct } \\
\text { resection, } \\
\text { portal } \\
\text { lymphaden } \\
\text { ectomy, } \\
\text { partial } \\
\text { hepatecto } \\
\text { my } \\
\text { segments } \\
\text { IV and V }\end{array}$ & $\begin{array}{l}\text { Cystic duct } \\
\text { excision, } \\
\text { portal } \\
\text { lymphadene } \\
\text { ctomy, } \\
\text { partial } \\
\text { hepatectomy } \\
\text { segments IV } \\
\text { and V }\end{array}$ & $\begin{array}{l}\text { Cystic duct } \\
\text { excision, } \\
\text { common bile } \\
\text { duct } \\
\text { exploration } \\
\text { with } \\
\text { removal of } \\
\text { stone }\end{array}$ & $\begin{array}{l}\text { Bile duct } \\
\text { resection } \\
\text { and portal } \\
\text { lymphaden } \\
\text { ectomy }\end{array}$ & $\begin{array}{l}\text { Cystic } \\
\text { duct } \\
\text { resection }\end{array}$ & $\begin{array}{l}\text { Cystic duct } \\
\text { resection }\end{array}$ & $\begin{array}{l}\text { Cystic duct } \\
\text { resection }\end{array}$ \\
\hline $\begin{array}{l}\text { Operative } \\
\text { findings }\end{array}$ & $\begin{array}{l}\text { Palpable } \\
\text { mass at } \\
\text { cystic duct } \\
\text { remnant, } \\
\text { enlarged } \\
\text { portal } \\
\text { lymph } \\
\text { nodes }\end{array}$ & None & $\begin{array}{l}\text { Common } \\
\text { bile duct } \\
\text { stones }\end{array}$ & $\begin{array}{l}\text { Palpable } \\
\text { mass at } \\
\text { cystic duct } \\
\text { remnant } \\
\text { No liver } \\
\text { lesions } \\
\text { identified }\end{array}$ & None & None & None \\
\hline Pathology & $\begin{array}{l}\text { Cholangio } \\
\text { carcinoma } \\
(\mathrm{T} 2 \mathrm{~N} 1) \\
4 / 6 \text { nodes } \\
\text { positive }\end{array}$ & $\begin{array}{l}\text { No evidence } \\
\text { of } \\
\text { malignancy } \\
\text { or dysplasia }\end{array}$ & $\begin{array}{l}\text { No evidence } \\
\text { of } \\
\text { malignancy } \\
\text { or dysplasia }\end{array}$ & $\begin{array}{l}\text { No } \\
\text { evidence } \\
\text { of } \\
\text { malignanc } \\
\text { y or } \\
\text { dysplasia }\end{array}$ & $\begin{array}{l}\text { No } \\
\text { evidence } \\
\text { of } \\
\text { malignan } \\
\text { cy or } \\
\text { dysplasia }\end{array}$ & $\begin{array}{l}\text { No evidence } \\
\text { of } \\
\text { malignancy } \\
\text { or dysplasia }\end{array}$ & $\begin{array}{l}\text { No evidence } \\
\text { of } \\
\text { malignancy } \\
\text { or dysplasia }\end{array}$ \\
\hline Status & $\begin{array}{l}\text { Deceased } \\
\text { during } \\
\text { follow-up } \\
\text { after } 15.3 \\
\text { months }\end{array}$ & $\begin{array}{l}\text { No evidence } \\
\text { of disease } \\
\text { after } 0.9 \\
\text { months }\end{array}$ & $\begin{array}{l}\text { No evidence } \\
\text { of disease } \\
\text { after } 16.0 \\
\text { months }\end{array}$ & $\begin{array}{l}\text { No } \\
\text { evidence } \\
\text { of disease } \\
\text { after } 25.6 \\
\text { months }\end{array}$ & $\begin{array}{l}\text { No } \\
\text { evidence } \\
\text { of } \\
\text { disease } \\
\text { after } 2.1 \\
\text { months }\end{array}$ & $\begin{array}{l}\text { No evidence } \\
\text { of disease } \\
\text { after } 0.5 \\
\text { months }\end{array}$ & Not reported \\
\hline
\end{tabular}

MRCP: Magnetic resonance cholangiopancreatography; PET: Positron emission tomography; CT: Computed tomography; ERCP: Endoscopic retrograde cholangiopancreatography; CBD: Common bile duct. 


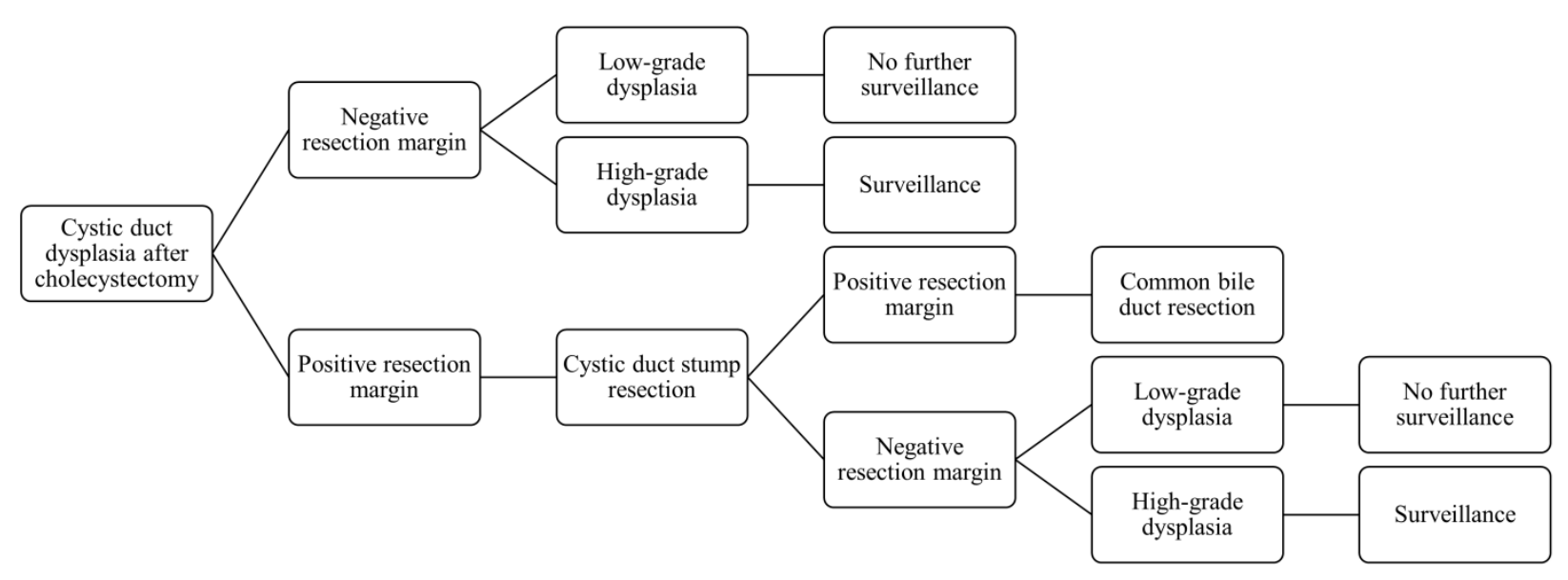

Figure 2: Possible therapeutic algorithm for the treatment of cystic duct dysplasia with positive resection margins.

According to the GRADE approach, due to sparse data and other limitations in the quality of selected studies, the overall quality of evidence of this systematic review was judged "very low" (level of evidence 5).

\section{DISCUSSION}

Cancers of the biliary tract could involve the intra- and extrahepatic ducts, gallbladder and ampulla. ${ }^{13}$ The involved biliary segment has been described to vary among different countries, being the intrahepatic carcinoma more common in Asia and the gallbladder cancer in South America. Gallstones are the most important risk factor for the development of a gallbladder cancer and in 70-90\% of cases of gallbladder cancer gallstones can be identified. ${ }^{14}$ Chronic inflammation, Caroli's disease, choledochal cysts, infectious diseases as well as a variety of biological and chemical toxins are further factors associated with biliary cancer development. ${ }^{14}$ The carcinogenesis of biliary neoplasm is thought to be a multi-step process from metaplasia to malignant degeneration. Antral metaplasia, hyperplasia, non-neoplastic polyps represent non-neoplastic lesions and can be found in around 9-59.5\% of cases after cholecystectomy. ${ }^{15,16}$ The bile-type epithelium with columnar cells and round to oval uniform nuclei differ from the dysplastic changes that are characterized by the loss of epithelium architecture, increased height of cells and nuclear crowding with presence of mitotic figures (Figure 3). While reactive changes blend gradually with the normal cells' architecture, real dysplasia has sharp demarcated areas adjacent to the normal biliary epithelium. ${ }^{6}$

Depending on the severity of atypia, dysplasia can be defined as either low- or high-grade. Terms like "moderate" or "severe" dysplasia, as well as "carcinoma in situ" are used to describe histological changes of biliary epithelium. Zen et al described two main types of premalignant dysplastic lesions as the biliary intraepithelial neoplasia (BilIN) and intraductal papillary neoplasms. ${ }^{17}$ The latter is considered less common, it is associated with ectasia of extrahepatic biliary ducts and cysts formation with an exophytic proliferation of biliary epithelium. Moreover, it can be associated with abdominal pain and jaundice.

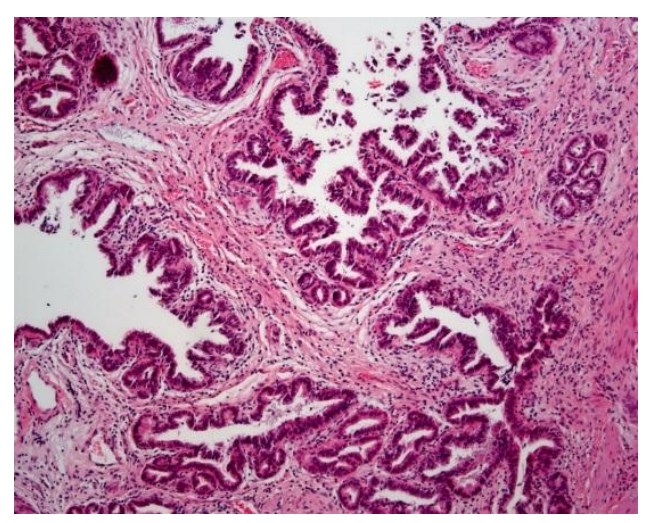

Figure 3: Histologic exam showing a low-grade dysplasia on the cystic duct stump.

Zen et al originally described BilIN as microscopic alterations, asymptomatic and not appreciable with imaging studies. BilIN is frequently detectable in specimens with invasive carcinoma and is an incidental finding in 1 to $3.5 \%$ of cholecystectomies. BilIN was recently classified by the World Hospital Organization according to the degree of atypia in BilIN1, BilIN2 and BilIN. ${ }^{17,18}$ Therefore, BilIN1 corresponds to low-grade, BilIN2 to intermediate grade and BilIN3 to a high-grade of dysplasia. Although this grading-system may be useful, in daily practice it is easier to apply a two-tiered system (low-grade and high-grade dysplasia).

The 5-year survival rate of patients with cholangiocarcinoma is thought to be around 5-10\%. An improved overall survival can only be achieved through a complete surgical resection with tumour-free margins but, unfortunately, these surgical results are difficult to 
achieve as frequently an advanced disease is diagnosed. ${ }^{19,20}$ Mizumoto et al reported a 5-year survival rate for early bile duct cancer of $100 \% .{ }^{21}$ Kurosaki et al reported a 5-year survival rate for 7 patients with pT1 bile duct cancer of $86 \% .^{22}$ Therefore, in case of biliary dysplasia, strategies involving prophylactic surgical resections or detection of cancers at early stage could have a dramatic impact on patient's prognosis.

Bickenbach et al reported a series of five patients with high-grade dysplasia at the cystic duct margin after cholecystectomy without preoperative evidence of malignancy. ${ }^{10}$ One of the five patients was found to have a carcinoma and deceased after 15 months despite proper surgery and adjuvant chemotherapy. From this small series, the authors concluded that the risk of underlying bile duct cancer in case of high-grade dysplasia at the cystic stump is not neglectable, as about $10 \%$ of biliary carcinomas are multifocal. So, high-grade dysplasia of the cystic stump could represent multifocal neoplastic changes of biliary ducts or express a wide extension of an underlying malignancy. In a recent case report, Moslim et al suggested the surgical intervention with excision and reconstruction of the main duct in case of positive cystic duct resection margins. ${ }^{11}$ More recently, Cianfarani et al reported a case of positive resection margins for lowgrade dysplasia on the cystic duct that was successfully surgical treated with a cystic stump resection. ${ }^{12}$

The lack of literature about the surveillance of cystic duct dysplasia makes difficult to draw conclusions. A possible management algorithm is shown in Figure 2. Due to the known progression to carcinoma and the multifocality, a multidisciplinary board evaluation in case of dysplasia of the cystic duct is strongly advisable. The surgical treatment of positive resection margins after cholecystectomy with high-grade dysplasia should be considered mandatory. The treatment of cases with lowgrade dysplasia should be tailored on patient's age and general conditions, but a surgical resection can be a reasonable option. Due to the high rate of dysplasia multifocality, an optimal surveillance program should be considered in patient with low- and high-grade dysplasia. There is no evidence that supports one or the other method, so that its choice should be based on the local experience and resources. Magnetic resonance cholangiopancreatography (MRCP), endoscopic retrograde cholangiopancreatography (ERCP) with SpyGlass cholangioscopy, echoendoscopy and regular liver function tests can play a role in surveillance programs.

\section{Limitations}

The main limitation of our study is the sparse data available in literature on positive resection margins for dysplasia after cholecystectomy. A case series and two case reports make difficult to draw proper conclusions. Nevertheless, literature on the gallbladder and the biliary tree dysplasia provides sufficient data to propose a possible treatment algorithm for this uncommon condition..

\section{CONCLUSION}

Patients with positive resection margins for dysplasia after cholecystectomy should be considered for a surgical treatment. The latter depends on several factors related to the patient and the grade of dysplasia itself. Simple cystic duct stump excision has been suggested and it seems to be safe and effective with no evidence of recurrence during follow-up when a R0 resection is achieved. A multidisciplinary approach and a surveillance program should be always taken into account. Our possible management algorithm of this uncommon disease needs to be validated and should be the matter of future studies.

\section{Funding: No funding sources \\ Conflict of interest: None declared \\ Ethical approval: Not required}

\section{REFERENCES}

1. Schirmer BD, Winters KL, Edlich RF. Cholelithiasis and cholecystitis. J Long Term Eff Med Implants. 2005;15:329-38.

2. Gurusamy KS, Davidson BR. Gallstones. BMJ. 2014;348:g2669.

3. Talreja V, Ali A, Khawaja R, Rani K, Samnani SS, Farid FN. Surgically resected gall bladder: is histopathology needed for all?. Surg Res Pract. 2016;2016:9319147.

4. Roa I, Ibacache G, Munoz S, de Aretxabala X. Gallbladder cancer in Chile: Pathologic characteristics of survival and prognostic factors: analysis of 1,366 cases. Am J Clin Pathol. 2014;141:675-82.

5. Wrenn SM, Callas PW, Abu-Jaish W. Histopathological examination of specimen following cholecystectomy: Are we accepting resect and discard?. Surg Endosc. 2017;31:586-93.

6. Katabi N. Neoplasia of gallbladder and biliary epithelium. Arch Pathol Lab Med. 2010;134:1621-7.

7. Rais R, Gonzalez I, Chatterjee D. Dysplasia in gallbladder: what should we do?. J Gastrointest Surg. 2019;23:686-9.

8. Moher D, Liberati A, Tetzlaff J, Altman DG. PRISMA Group. Preferred reporting items for systematic reviews and meta-analyses: the PRISMA statement. J Clin Epidemiol 2009;62:1006-12.

9. Balshem H, Helfand M, Schunemann HJ, Oxman AD, Kunz R, Brozek J, et al. GRADE guidelines: Rating the quality of evidence. J Clin Epidemiol. 2011;64:401-6.

10. Bickenbach KA, Shia J, Klimstra DS, DeMatteo RP, Fong Y, Kingham TP, et al. High-grade dysplasia of the cystic duct margin in the absence of malignancy after cholecystectomy. HPB (Oxford). 2011;13:865-8. 
11. Moslim MA, Tang A, Morris-Stiff G. Management of high-grade dysplasia of the cystic duct after cholecystectomy. BMJ Case Rep. 2017;2017.

12. Cianfarani A, Mongelli F, Di Giuseppe M, La Regina D. Dysplasia of cystic duct and positive resection margins after cholecystectomy: a challenging decision making process. J Surg. 2019;4:1195.

13. Kloppel G, Adsay V, Konukiewitz B, Kleeff J, Schlitter AM, Esposito I. Precancerous lesions of the biliary tree. Best Pract Res Clin Gastroenterol. 2013;27:285-97.

14. Marcano-Bonilla L, Mohamed EA, Mounajjed T, Roberts LR. Biliary tract cancers: epidemiology, molecular pathogenesis and genetic risk associations. Chin Clin Oncol. 2016;5:61.

15. Esendagli G, Akarca FG, Balci S, Argon A, Erhan SS, Turhan N, et al. A retrospective evaluation of the epithelial changes/lesions and neoplasms of the gallbladder in Turkey and a review of the existing sampling methods: a multicentre study. Turk Patoloji Derg. 2018;34:41-8.

16. Mukhopadhyay S, Landas SK. Putative precursors of gallbladder dysplasia: a review of 400 routinely resected specimens. Arch Pathol Lab Med. 2005;129:386-90.

17. Zen Y, Aishima S, Ajioka Y, Haratake J, Kage M, Kondo F, et al. Proposal of histological criteria for intraepithelial atypical/proliferative biliary epithelial lesions of the bile duct in hepatolithiasis with respect to cholangiocarcinoma: preliminary report based on interobserver agreement. Pathol Int. 2005;55:180-8.

18. Akiba J, Nakashima O, Hattori S, Tanikawa K, Takenaka M, Nakayama M, et al. Clinicopathologic analysis of combined hepatocellularcholangiocarcinoma according to the latest WHO classification. Am J Surg Pathol. 2013;37:496-505.

19. Cillo U, Fondevila C, Donadon M, Gringeri E, Mocchegiani F, Schlitt HJ, et al. Surgery for cholangiocarcinoma. Liver Int. 2019;39(S1):143-55.

20. Cha JM, Kim MH, Jang SJ. Early bile duct cancer. World J Gastroenterol. 2007;13:3409-16.

21. Mizumoto R, Ogura Y, Kusuda T. Definition and diagnosis of early cancer of the biliary tract. Hepatogastroenterol. 1993;40:69-77.

22. Kurosaki I, Tsukada K, Watanabe H, Hatakeyama K. Prognostic determinants in extrahepatic bile duct cancer. Hepatogastroenterol. 1998;45:905-9.

Cite this article as: Mongelli F, Cianfarani A, Di Giuseppe M, Ferrario di Tor Vajana A, Saporito A, Garofalo F, et al. Cystic duct dysplasia after cholecystectomy: a systematic review of the literature. Int Surg J 2019;6:4192-7. 